\title{
In situ detection of transcripts of the myogenic factor MyoD in whole chicken embryos
}

\author{
Jane E. Gabriel ${ }^{1}$,Helena J. Alves ${ }^{1}$, Lucia E. Alvares ${ }^{1}$, Gilberto S. Schmidt ${ }^{2}$ and Luiz L. Coutinho
}

\begin{abstract}
In situ hybridization has provided insights into the molecular basis of skeletal myogenesis during embryonic development. In situ detection of different muscle-specific regulatory factors in whole embryos has been described. Spatial and temporal expression patterns of these factors differed among species. The expression pattern of MyoD in whole chicken embryos was studied via in situ hybridization using a probe obtained by the reverse transcription - polymerase chain reaction (RT-PCR) technique. In newly formed somites (embryos of stage 12), MyoD mRNA transcripts were detected along the anterior to posterior axis of somites immediately adjacent to the neural tube, whereas in mature somites (embryos of stage 24), MyoD transcripts were detected throughout the entire somite. These results indicate that MyoD expression is important for initiating and maintaining the avian myogenic system.
\end{abstract}

\section{INTRODUCTION}

Skeletal myogenesis during embryonic development involves a large spectrum of gene activation and cellular signalling mechanisms. Several tissue-specific genes responsible for the determination and differentiation of muscle cells have been identified. Recent studies of the molecular mechanisms involved in skeletal muscle development have shown that myogenesis is strictly dependent on a family of muscle-specific transcription factors, including MyoD, myogenin, myf-5 and MRF-4 (Emerson Jr., 1993; Cossu et al., 1996). The introduction of expression vectors for these factors into non-muscle cells results in a program of muscle differentiation (Weintraub et al., 1989; Hopwood et al., 1991; Miner et al., 1992), indicating that such factors play an essential role in skeletal muscle determination and differentiation.

Whole mount in situ hybridization analysis is a powerful tool for investigating the regulatory processes involved in myogenesis since it provides a clear view of the spatial pattern of mRNA expression and eliminates some steps that demand considerable effort and ability, such as sectioning and orientation of the sections (Coutinho et al., 1992). Previous studies have shown that myogenic regulatory genes are expressed during early embryogenesis. In situ analyses of mouse embryos have shown that in somites myf- 5 is expressed first, followed sequentially by myogenin, MRF-4, and MyoD (Bober et al., 1991; Hinterberger et al., 1991). Similar experiments in quail have shown that qmf1 (MyoD) is activated first, followed by myf-5 (qmf3) and myogenin (qmf2) (Pownall and Emerson Jr., 1992a; Coutinho et al., 1993).
Recent studies (Coutinho et al., 1992, 1993) have suggested a relationship between myogenic factor expression and skeletal muscle deposition in poultry. They detected a delay in somite formation and qmf $1, \mathrm{qmf} 2, \mathrm{qmf} 3$ and myosin expression in quail embryos from a line selected for weight gain. In contrast, quail selected for a decrease in weight gain showed advanced somite formation and qmf 1 expression.

The expression pattern of myogenic factors in poultry has been investigated mainly in quail embryos (Pownall and Emerson Jr., 1992b). Little has been reported on the in situ detection of these factors in whole chicken embryos. Pourquié et al. (1995) reported that the messages detected using a heterologous MyoD probe for in situ hybridization analyses were stronger in quail than in chicken embryos. We investigated the transcript expression pattern of the myogenic factor MyoD in whole chicken embryos in in situ hybridization analysis using a probe obtained by the reverse transcription - polymerase chain reaction (RT-PCR) technique.

\section{MATERIAL AND METHODS}

\section{Egg incubation and embryo collection}

Chicken eggs of Ross line, obtained from the poultry section of the Escola Superior de Agricultura "Luiz de Queiroz" (ESALQ-USP), were incubated in a humidified atmosphere at $37^{\circ} \mathrm{C}$ for two or five days. When collected the embryos had 16 or 27 pairs of somites, corresponding to stages 12 and 24, respectively (Hamburger and Hamilton, 1951). The embryos were fixed in $4 \%$ paraformaldehyde in PBS $\left(0.14 \mathrm{mM} \mathrm{NaCl}, 2.7 \mathrm{mM} \mathrm{KCl}, 10 \mathrm{mM} \mathrm{Na}_{2} \mathrm{HPO}_{4}\right.$ and 1.8 $\mathrm{mM} \mathrm{KH}_{2} \mathrm{PO}_{4}, \mathrm{pH}$ 7.4). The embryonic membranes were re- 
moved to facilitate access of the probe to the tissues, and the embryos then were stored in $70 \%$ ethanol at $-20^{\circ} \mathrm{C}$ until used.

\section{Preparation of RNA antisense MyoD digoxigenin-labelled probe}

The RNA antisense MyoD probe used was obtained by the reverse transcription - polymerase chain reaction (RTPCR) technique as described by Bales et al. (1993). Total RNA was isolated from 96-h chicken embryos as reported by Chomczynski and Sacchi (1987). One microgram of total RNA was used in the reverse transcription reactions to obtain cDNA. After denaturing the sample for $10 \mathrm{~min}$ at $70^{\circ} \mathrm{C}$, PCR buffer $\left(2.5 \mathrm{mM} \mathrm{MgCl}_{2}, 1 \mathrm{mM}\right.$ dNTPs, $50 \mathrm{ng}$ of oligo primer (dT) (Gibco) and 200 units of the reverse transcriptase enzyme Superscript II (Gibco)) was added to a final volume of $20 \mu \mathrm{l}$. The samples were incubated for 50 $\min$ at $42^{\circ} \mathrm{C}$, after which the reverse transcriptase was inactivated by heating $\left(15 \mathrm{~min}\right.$ at $\left.70^{\circ} \mathrm{C}\right)$, followed by treatment with 1 unit of RNAse $\mathrm{H}$ for $20 \mathrm{~min}$ at $37^{\circ} \mathrm{C}$, to destroy the RNA templates. Ten percent of the total cDNA reaction volume was amplified directly by the PCR.

The primers used for the amplifications were described by Lin-Jones and Hauschka (1996), except that the reverse primer was designed from a combination of the complementary MyoD gene sequence with the T7 bacteriophage promoter sequence in its 5' end (underlined bases). This primer also had three bases (GGG) corresponding to the initial transcription site for the in vitro transcription reactions. The direct and reverse sequences were 5'TACCCAGTGCTGGAGCACTA-3' and 5'-TAATACGACTC ACTATAGGGGTCTTGGAGCTTGCTGAAC-3', respectively.

PCR was performed using final concentrations of 10 pmol of MyoD specific primers, $10 \mathrm{mM}$ of each dNTP, 1.5 $\mathrm{mM} \mathrm{MgCl} 2$ and 2 units of Taq DNA polymerase (Gibco) in a final volume of $50 \mu \mathrm{l}$. The amplification protocol consisted of 35 cycles of denaturation at $95^{\circ} \mathrm{C}$ for $1 \mathrm{~min}$, primer annealing at $57^{\circ} \mathrm{C}$ for $1 \mathrm{~min}$, and extension at $74^{\circ} \mathrm{C}$ for 1 min. The 493-bp amplified product was separated in an agarose gel, purified on a Quiagen column and used in the in vitro transcription reactions. Approximately $200 \mathrm{ng}$ of the purified product was incubated for $2 \mathrm{~h}$ at $37^{\circ} \mathrm{C}$ with digoxigenin-labelled UTP and 40 units of T7RNA polymerase enzyme (Boehringer Mannheim). Alternatively, a PCR primer without the T7 bacteriophage promoter sequence at its 5 ' end was used to clone the amplified product in the plasmid pGEM4Z (Promega). This plasmid contains the $\mathrm{T} 7$ promoter sequence and was also used to generate anti-sense probes. The MyoD anti-sense probe ( $470 \mathrm{bp}$ ) was submitted to alkaline hydrolysis in two volumes of carbonate buffer $\left(60 \mathrm{mM} \mathrm{Na}_{2} \mathrm{CO}_{3}, 40 \mathrm{mM} \mathrm{NaHCO}_{3}, \mathrm{pH} 10.2\right)$ for $5 \mathrm{~min}$ at $60^{\circ} \mathrm{C}$ to reduce its size and increase its access to tissues. The hydrolysis was terminated by adding an equal volume of neutralizing solution ( $1 \mathrm{M}$ Tris- $\mathrm{HCl}, \mathrm{pH} 8.0$, containing $1.5 \mathrm{M} \mathrm{NaCl})$. Hydrolyzed fragments were precipi- tated with $70 \mu \mathrm{g}$ of glycogen $/ \mathrm{ml}$ and three volumes of ethanol. The antisense digoxigenin-labelled MyoD RNA probe was stored in hybridization solution $(50 \%$ formamide, $4 \mathrm{x}$ SSC, $1 x$ Denhardt's solution, $0.5 \mu \mathrm{g}$ of heat-denatured herring sperm $\mathrm{DNA} / \mathrm{ml}, 0.25 \mu \mathrm{g}$ of yeast tRNA/ml and $10 \%$ dextran sulfate) at $-70^{\circ} \mathrm{C}$.

\section{Whole mount in situ hybridization}

The methodology for in situ hybridization has been described by Coutinho et al. (1992). Briefly, embryos were washed in PBS plus $0.3 \%$ Triton X-100 (PBT) and digested with $30 \mu \mathrm{g}$ of proteinase $\mathrm{K} / \mathrm{ml}$ for $7-15 \mathrm{~min}$ at $37^{\circ} \mathrm{C}$, after which they were pre-hybridized in $100 \mu$ of hybridization solution for $3 \mathrm{~h}$ at $63^{\circ} \mathrm{C}$. Hybridization was done in a new hybridization solution containing an antisense digoxigeninlabelled RNA probe (final concentration, $0.3 \mu \mathrm{g} / \mathrm{ml}$ ) for 45 $\mathrm{h}$ at $63^{\circ} \mathrm{C}$. After washing in hybridization solution (without probe) for $3 \mathrm{~h}$ at $63^{\circ} \mathrm{C}$ and $12 \mathrm{~h}$ at $63^{\circ} \mathrm{C}$, the embryos were finally washed at room temperature in $80 \%$ hybridization solution (Hyb)/20\% PBT, 60\% Hyb/40\% PBT, 40\% Hyb/ $60 \% \mathrm{PBT}, 20 \% \mathrm{Hyb} / 80 \% \mathrm{PBT}$ (20 min each) and twice in PBT (1 h each). Immunological detection was done with an anti-digoxigenin antibody conjugated to alkaline phosphatase at a dilution of 1:2000. MyoD transcript signals were detected by a colorimetric reaction with chromogenic substrates as described in the Genius System protocol (Boehringer Manheim). Color development reaction was carried out for $5-16 \mathrm{~h}$ and was interrupted by incubation in TE buffer (10 mM Tris-HCl, pH 8.0, 1 mM EDTA). The embryos were photographed using a Leica WILD MPS52 photomacroscope and then stored at $4^{\circ} \mathrm{C}$.

\section{RESULTS AND DISCUSSION}

Skeletal muscle lineage during embryonic development is determined by regulatory factors that activate muscle-specific genes. Of these factors, MyoD is the first to be expressed and has an essential role in skeletal myogenesis. MyoD transcripts were detected in the medial dorsal side of somites along the anterior to posterior axis of a stage 12 embryo (Figure 1A). No signal was detected in the absence of probe (negative control embryos), thus confirming the specificity of hybridization. These observations confirm those of de la Brousse and Emerson Jr. (1990) and Coutinho et al. (1992). MyoD was detected in all the somites of stage 24 embryos, with expression extending across the entire somite (Figure 1B). This finding indicates that MyoD expression is important not only for the initiation but also for the maintenance of the myogenic program.

The probe synthesized as described above provided excellent results in in situ hybridizations, since the use of specific primers and RT-PCR produced a homologous product without the need to clone the gene of interest. The inclusion of a transcription site for T7RNA polymerase in the reverse primer facilitated production of the antisense 

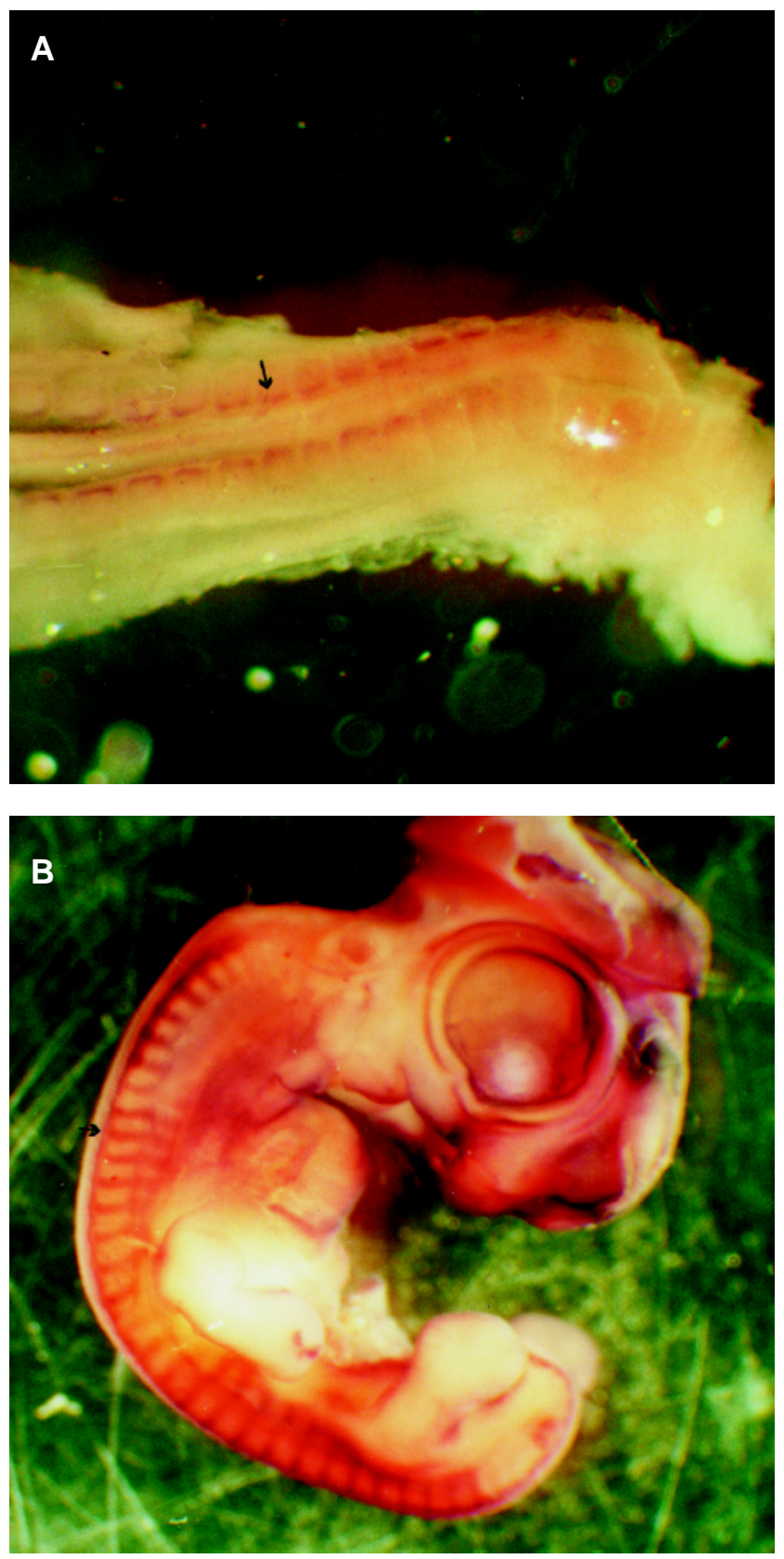

Figure 1 - MyoD expression pattern in developing chicken embryos. A and B - Whole mounts of stage 12 (two days) and stage 24 (five days) chicken embryos, respectively, hybridized in situ with digoxigenin-labelled MyoD anti-sense probe. The embryo in Figure 1A is oriented in a cranial to caudal direction from right to left. The dark brown signal (arrows) along the medial side of the somites indicates the presence of MyoD transcripts.

RNA probe. This was particularly interesting since RNA probes are recommended for in situ hybridization because they allow an increase in hybridization temperature and greater signal specificity. Most in situ hybridizations for myogenic factors in studies of avian embryogenesis have been done in serially sectioned embryos. Our results with whole embryos demonstrate the same expression pattern for MyoD transcripts as that seen in sectioned quail em- bryos (Pownall and Emerson Jr., 1992a). In addition to eliminating steps such as embryo infiltration during the in situ procedure, the method described here allows examination of an entire embryo at once.

Comparative studies have shown that the sequence of myogenic factor activation during myogenesis is different in poultry and mammals (Emerson Jr., 1993). Analysis of myogenic factors during embryonic development of mice demonstrated that in somites myf- 5 is expressed first followed by myogenin, MRF-4, and MyoD1 (Bober et al., 1991; Hinterberger et al., 1991). In contrast, Pownall and Emerson Jr. (1992b) and Coutinho et al. (1993) reported that in quail MyoD was the first myogenic factor activated during embryonic development, followed by myogenin and myf-5. The biological significance of differences in the temporal expression of myogenic factors in poultry and mammals is still unknown.

In conclusion, the expression pattern of the myogenic factor MyoD is similar in chicken and quail embryos. In newly formed somites, MyoD transcripts were detected in the medial dorsal region, whereas in mature somites, expression was observed throughout the entire somite. These observations indicate that MyoD plays a role in the initiation and maintenance of myogenesis.

\section{ACKNOWLEDGMENTS}

The authors thank the Secretaria de Ciência e Tecnologia do Estado de São Paulo, FAPESP and EMBRAPA/CNPSA for financing this study. J.E.G. and L.E.A. are recipients of Ph.D. scholarships from FAPESP; H.J.A. is the recipient of an MSc scholarship from CNPq and G.S.S. and L.L.C. are recipients of research fellowships from CNPq. Publication supported by FAPESP.

RESUMO

A detecção in situ de diferentes fatores regulatórios músculoespecíficos vem sendo uma prática muito empregada para o entendimento das bases moleculares envolvidas no processo de formação do tecido muscular esquelético durante o desenvolvimento embrionário em diferentes organismos. O objetivo deste estudo foi investigar o padrão de expressão dos transcritos do fator miogênico MyoD em embriões inteiros de galinha por análises de hibridização in situ, usando uma sonda obtida a partir de ensaios de transcrição reversa e reação em cadeia da polimerase (RT-PCR). Nos somitos recém-formados (embriões no estádio 12), os transcritos de MyoD foram detectados na porção mediana dos somitos posicionados imediatamente adjacentes ao tubo neural, enquanto nos somitos maduros (embriões no estádio 24), a expressão do gene do MyoD foi observada em toda a região dos somitos. Tais resultados indicam que a expressão do MyoD é importante no processo de determinação e manutenção da miogênese nas aves.

\section{REFERENCES}

Bales, K.R., Hannon, K., Smith II, C.K. and Santerre, R.F. (1993). Singlestranded RNA probes generated from PCR-derived DNA templates. Mol. Cell. Probes 7: 269-275. 
Bober, E., Lyons, G.E., Braun, T., Cossu, G., Buckingham, M. and Arnold, H.H. (1991). The muscle regulatory gene, myf-6 has a biphasic pattern of expression during early mouse development. J. Cell Biol. 113: 12551265.

Chomczynski, P. and Sacchi, N. (1987). Single-step method of RNA isolation by acid guanidinum thiocyanate-phenol-chloroform extraction. Anal. Biochem. 162: 156-159.

Cossu, G., Tajbakhsh, S. and Buckingham, M. (1996). How is myogenesis initiated in the embryo? Trends Genet. 12: 218-223.

Coutinho, L.L., Morris, J. and Ivarie, R. (1992). Whole mount in situ detection of low abundance transcripts of the myogenic factor qmf 1 and myosin heavy chain protein in quail embryos. Biotechniques 13: 722724.

Coutinho, L.L., Morris, J., Marks, H.L., Buhr, J.R. and Ivarie, R. (1993). Delayed somite formation in a quail line exhibiting myofiber hyperplasia is accompanied by delayed expression of myogenic regulatory factors and myosin heavy chain. Development 117: 563-569.

de la Brousse, C.F. and Emerson Jr., C.P. (1990). Localized expression of myogenic regulatory gene qmf 1 in the somite dermatome of avian embryos. Genes Dev. 4: 567-581.

Emerson Jr., C.P. (1993). Skeletal myogenesis: genetics and embryology to the fore. Genes Dev. 3: 265-274.

Hamburger, V. and Hamilton, H.L. (1951). A series of normal stages in the development of the chick embryo. J. Morphol. 88: 49-82.

Hinterberger, T.J., Sassoon, D.A., Rhodes, S.J. and Konicezny, S.F. (1991).
Expression of the muscle regulatory factor MRF4 during somite and skeletal myofiber development. Dev. Biol. 147: 144-156.

Hopwood, N.D., Pluck, A. and Gurdon, J.B. (1991). Xenopus myf-5 marks early muscle cells and can activate muscle genes ectopically in early embryos. Development 111: 551-560.

Lin-Jones, J. and Hauschka, S.D. (1996). Myogenic determination factor expression in the developing avian limb bud: an RT-PCR analysis. Dev. Biol. 174: 407-422.

Miner, J.H., Miller, J.B. and Wold, B.J. (1992). Skeletal muscle phenotypes initiated by ectopic MyoD in transgenic mouse heart. Development 114: 853-860.

Pourquié, O., Monique, C., Bréant, C. and Le Douarin, N.M. (1995). Control of somite patterning by signals from the lateral plate. Proc. Natl. Acad. Sci. USA 92: 3219-3223.

Pownall, M.E. and Emerson Jr., C.J. (1992a). Sequential activation of three myogenic regulatory genes during somite morphogenesis in quail embryos. Dev. Biol. 151: 67-79.

Pownall, M.E. and Emerson Jr., C.J. (1992b). Molecular and embryological studies of avian myogenesis. Semin. Dev. Biol. 3: 229-241.

Weintraub, H., Tapscott, S.J., Davis, R.L., Thayer, M.J., Adam, M.A., Lassar, A.B. and Miller, A.D. (1989). Activation of muscle specific genes in pigment, nerve, fat, liver, and fibroblast cell lines by forced expression of MyoD. Proc. Natl. Acad. Sci. USA 86: 5434-5438.

(Received September 21, 1998) 